\title{
Sociolinguistic Challenges of Prosecuting Rape as Genocide at the International Criminal Tribunal for Rwanda: the Trial of Jean-Paul Akayesu
}

\begin{abstract}
The trial of Jean-Paul Akayesu is by far the most well known and widely discussed case at the International Criminal Tribunal for Rwanda (ICTR), a distinction that can be attributed to the fact that it was groundbreaking for several reasons. However, with regard to the importance of this trial both as a precedent for subsequent ICTR cases and within the broader context of international jurisprudence, its most significant contribution has undoubtedly been the recognition and prosecution of rape as a means of perpetrating genocide. The task of collecting admissible evidence to that end was heavily impacted by the necessity of interpreting and translating witness testimonies from their original language of expression, Kinyarwanda, into the working languages of the Tribunal, French and English. The multiple challenges associated with this translation process concerned not only questions of semantic equivalence of specific lexical terms. They also highlighted the considerable 'cultural collision' that occurred in the courtroom between the Rwandan witnesses and the international judiciary. This article elucidates the complex task faced by the courtroom interpreters in navigating these linguistic and sociocultural considerations underpinning the evocations of rape within the evidentiary framework of the Akayesu trial.
\end{abstract}

\section{Introduction}

The International Criminal Tribunal for Rwanda (ICTR) was established in Arusha, Tanzania in 1995 for the purpose of bringing the key perpetrators of the 1994 Tutsi genocide in Rwanda to justice. From the UN's perspective, one of the ICTR's strengths was that it would implement the best practices of international law in pursuit of its core objective, that of providing a fair trial. [41, p. 55] The trial of Jean-Paul Akayesu is by far the most well known and widely discussed case at the ICTR, a distinction attributable to the fact that it is noteworthy for several reasons. It was the first case to be brought before the Tribunal, with proceedings beginning on 9 January 1997. The court's ruling handed down on 2 September 1998 was also a landmark for international justice, as it constituted the first conviction for the crime of genocide since the official definition of that term in the 1948 UN Convention. In this regard, the Akayesu trial was particularly important insofar as 'almost every legal question had to be decided with no precedents.' [17] The practices regarding the collection and evaluation of evidence and the subsequent rulings made during the Akayesu trial were therefore seen as invaluable in providing contextually appropriate precedents for subsequent ICTR courtroom practices and judgments. As Chief Prosecutor Pierre-Richard Prosper commented at the time, the Akayesu trial 'gives us a road map of how we are to proceed.' [17]

In terms of the legacy of the Akayesu trial beyond the framework of the ICTR, attention has often focused on its groundbreaking recognition and prosecution of rape as a means of perpetrating genocide. In this connection, a significant contribution was that the Trial Chamber 'articulated the seminal definitions of rape and sexual violence in international criminal law.' [3, p. 318] For these reasons, the Akayesu trial has been the subject of numerous studies, particularly on the part of scholars working in the areas of jurisprudence and feminist or gender studies. [See for example 4, 14, 9] However, a significant feature of the courtroom proceedings 
that has so far attracted only limited critical attention is the impact of the interpreting and translation process on the effective communication of the content of the testimonies tendered as evidence. Over $90 \%$ of the Rwandan witnesses who appeared at the ICTR chose to testify in their mother tongue, Kinyarwanda.[43, p. 581] These testimonies were then translated into the two working languages of the Tribunal, French and English, to enable the evidence to be evaluated by the international judiciary. On the specific subject of rape, core considerations include the fact that there is no word in Kinyarwanda for the crime of rape. Moreover, in Rwandan society, rape is a subject that is considered taboo. [7, p. 88] When individuals resolve to break their silence and speak about this highly invasive act of aggression, they must therefore navigate the constraints imposed both by the social conventions and the lack of precise terminology. These factors raise important questions for the judicial process. Firstly, when there is extreme euphemisation or ellipsis in the source language - in this case, Kinyarwanda - , how does this impact on the ethical precept of accuracy underpinning the work of the courtroom interpreter/translator? Secondly, in relation to the objective of a fair trial, to what extent should these particular sociocultural and linguistic considerations be taken into account in order to determine whether the relatively scant details provided in the testimonies constitute admissible evidence?

The significance of these questions extends far beyond the specific parameters of the Akayesu case and the ICTR, as it identifies the pivotal role played by interpreters and translators within any judicial framework where the challenge of communicating across different languages and cultures is incontrovertible. As Ellen Elias-Bursać observes in relation to the work of the language service at International Criminal Tribunal for the Former Yugoslavia (ICTY), 'translation and the forces it sets in motion often influence jurisprudence and shape international justice.' [10, p. 35] Similarly, Joshua Karton highlights the importance of the work of interpreters in international criminal courts, citing examples from the Nuremberg Trials, the ICTR and the ICTY. He expresses his concern that crucial elements may well be 'lost in translation', thereby impacting both on the specific ruling in the given case and also on what he calls the 'rightness' and 'fairness' of international judicial procedures. [13, p. 2.]

This article will explore these important issues through the example of the Akayesu case and the challenges of prosecuting rape as genocide. It will begin by contextualising the specific focus on evocations of rape by examining broader considerations relating to the interpreting and translating process that was so crucial to the operations at the ICTR. It will then provide a close analysis of salient passages evoking rape that are drawn from testimonies in the Akayesu trial to elucidate how that crime was evoked by witnesses and how those words were translated by the courtroom interpreters. It will finally reflect on the heritage of the Akayesu trial within the ICTR, particularly in terms of the recognition of the importance of considerations relating to language for the judicial process.

\section{Methodological framework}

The methodological approach used in this discussion is informed by both discourse analysis and translation studies. My analysis is grounded in the close critical study advocated by systemic functional linguistics (SFL). Systemic theory 'is concerned with language in its entirety, so that whatever is said about one aspect is to be understood always with reference to the total picture.'[11, p. 20] Context is a crucial consideration for SFL scholars, because of its fundamental role in establishing meaning. The language used to evoke the genocide is influenced not only by personal experiences and associated considerations of subjectivity, but 
also by the specific context within which it is formulated. The broadest level of context in SFL is known as genre: this is defined by Martin and Rose as a 'recurrent configuration of meanings [that] enact the social practices of a given culture.' $[15, p$ 6] An important premise of genre theory is that there are conventional ways of talking about things in any given society or culture. In Rwanda, for example, there is a long oral tradition that is still very important in contemporary society. Quoting from proverbs, sayings and the 'umugani', the tales from traditional folklore, is a very common feature of discourse formulated in the Kinyarwanda language.[See 8, p. 106] Similarly, there are subjects that were long deemed to be taboo in Rwandan society, notably matters of a sexual nature. [12, p. 7] These sociocultural factors are important to acknowledge in relation to genre as they directly influence the rhetorical strategies adopted by Rwandans to evoke details pertaining to the genocide. Within the parameters of genre, the next subsidiary level is that of register, defined by SFL theorists as the set of linguistic options typically associated with a particular situation, such as the ICTR courtroom.[16] The examination of register within this article will take into account its three components: field (the nature of the event), tenor (the persons involved the relationship between them) and mode (the means of communication, in this case, the verbal testimony). In SFL a further level is that of discourse semantics, defined as the interface between context and language. It is therefore concerned with how the core denotational meaning of words and sentences is impacted by field, tenor and mode. These considerations are especially pertinent to the examination of how the crime of rape was expressed in the ICTR courtroom.

The discipline of translation studies is concerned with the theory, description and application of translation, defined as the process of communication of the meaning of words from a source language (SL) to a target language (TL). [See 36, 2] As well as being an umbrella term for this process, 'translation' more specifically refers to the rendering of texts from SL to TL in written form, whereas 'interpreting' or 'interpretation' refers to the oral transfer of meaning from the original spoken SL to the TL. The discussion in this article will focus exclusively on examples drawn from courtroom exchanges involving interpreters. [See 42] The cornerstone of the work of all translators and interpreters is the precept of accuracy. The translation must therefore take into account many of the basic elements of discourse analysis evoked above: genre, register, tenor and so on. A further important consideration in this regard is the distinction between denotation, the literal dictionary definition of a word, and connotation, the secondary associations evoked by the word beyond its core denotational meaning. Within a given SL context, effective communication operates on the premise that the connotations of a given word are familiar to both author/speaker and audience. Similarly, meaning is affected by the lexical field associated with any given word, which contributes relative nuances and gradations of intensity. Here the term 'lexical field' refers to semantically related words, such as kill, murder, slaughter, slay, execute, and so on. ${ }^{1}$ Each of these examples is embedded with particular connotations that also contribute to the meaning that is communicated in the SL. They must therefore be taken into account by the translator or interpreter in their search for an appropriate term to convey the same meaning as accurately as possible in the TL. [See 13, p. 26] Such an undertaking requires an awareness of the underlying resonance of the lexical and syntactical components that is quite distinct from grammatical and lexical competence on a superficial communicative level. From this perspective, the act of translation appears not simply as a linguistic process by which a term is 'trans-lated', i.e. moved from one place - or language - to another, but as a sociolinguistic act. Questions of strict denotational 'accuracy' are therefore relativised by the notion of the function of the text within

\footnotetext{
${ }^{1}$ The terms 'lexical field' and 'semantic field' are often used indiscriminately in English, whereas more rigorous distinction is applied in French between the terms 'champ lexical', meaning words associated with the same field and 'champ sémantique', referring to the different meanings attributed to the one word.
} 
its specific context, an important concern that has already been identified from the perspective of SFL.

Before moving on to discuss specific sociolinguistic challenges encountered in the ICTR courtroom by both witnesses and interpreters, it is pertinent to provide a brief explanation of the nature of the ICTR documentation accessible for analysis, particularly the witness testimonies cited below in the Akayesu case. The content of these testimonies is preserved in both written and audio format. The audio version is available in both French and English, where the predominant voice is the voice of the relevant interpreter, although there are some instances where the actual voices of the judges, prosecutors and defence counsellors can be heard. All of the witnesses cited in this article whose testimonies are relevant to the charge of rape benefited from the ICTR's witness protection programme. This meant that, at least in theory, they would not be identified and to this end, no video or audio recording of their testimonies was permitted. Consequently, in all these hearings, the witnesses' words are faint, deliberately distorted and frequently abridged. Reference has therefore also been made in the following discussion to the transcriptions of the hearings that are available in a French version and an English version. Preference has been given to the French version, as the original Kinyarwanda speech of the witness was firstly translated into French. That French version was then translated into English in a technique known as 'relay interpreting', where the intermediary language effectively becomes the new SL for the second phase of the interpreting procedure. However, the American Prosecutor Pierre-Richard Prosper spoke in his mother tongue, English; in the interests of accuracy, his words are therefore cited directly from the English transcript in the extracts examined below. In the light of these practical constraints, discussing the specific terminology used by the witnesses themselves to evoke the act of rape is an extremely difficult task. However, the Judgment of 2 September 1998 clearly identifies the main Kinyarwanda terms that were used. [34, para 152-154] Unless otherwise indicated, all translations of text cited below that was originally formulated in French and Kinyarwanda are by the author of this article.

\section{Sociocultural and linguistic challenges of interpreting and translating at the ICTR}

In establishing the ICTR, a core consideration in the pursuit of the objective of a fair trial was the composition of the judiciary. Article 11 of the UN resolution that created the Tribunal prescribes that 'The Chambers shall be composed of eleven independent judges, no two of whom may be nationals of the same State.' [44, p. 7.] This deliberate promotion of diversity among the judiciary can be seen as an attempt to reinforce notions of parity and integrity among the various participating nations, as well as to minimise potential bias on the part of different foreign countries for and against the Hutu and Tutsi ethnic groups in Rwanda. However, the rigorously international nature of the judges also carried significant disadvantages, notably the lack of important sociolinguistic and cultural knowledge regarding Rwandan society, which could significantly impact on the evaluation of evidence presented and therefore, ultimately, on the rulings handed down. To address these issues, provision was made for specific historical, political, cultural and also linguistic data to be supplied to the Tribunal, often in the guise of the testimonies of expert witnesses or submission of specialist documents. In 1998, for example, the Tribunal commissioned a 66 page report by three Rwandan linguists on the terminology and impact of the Kinyarwanda language used in the media in the period 1990-1994. [See 40] The fact nevertheless remains that many recorded instances illustrate the considerable sociocultural distance separating the Rwandans who 
appeared before the Tribunal and the members of the ICTR judiciary. The challenge posed by this distance was evident during the Akayesu trial, where, as Jose Alvarez has noted, the judges

(...) had to wrestle with subtleties in the way Rwandans express themselves that made it difficult to tell whether witnesses had actually witnessed acts that they were reporting or reporting what others had seen and told them. It is difficult to know whether the judges came to correct conclusions concerning such culturally sensitive questions. [1, p. 404]

Alvarez published a detailed evaluation of the ICTR in 1999, in which he clearly regards the Tribunal very much as a work in progress and argues for a number of changes to overcome what he identifies as its shortcomings. Of particular relevance to the present discussion is his suggestion of a 'controversial alternative': restructuring the ICTR's bench to include both a Hutu judge and a Tutsi judge. [1, p. 451] Alvarez notes that this would impact 'on both perceptions and results' and the main arguments he cites in support of this proposal include: the better resolution of difficult issues like credibility of witnesses; the generation of 'more nuanced accounts' of ethnic violence; and the provision of valuable insights into Rwandan law. $[1, \mathrm{p} .451]$ In other words, such judges could make a significant contribution to ensuring the 'fairness' of the Tribunal's proceedings by bridging the important identified gap in complex sociocultural understanding. Alvarez concludes by also mentioning the advantages that Rwandans may gain from such appointments, notably 'a greater sense of proprietorship in the ICTR' and encouragement of national reconciliation. [1, p. 451] A striking omission from this detailed list of arguments in favour of Rwandan participation on the bench is the question of language, that is, the immeasurable advantage provided by the fact that Rwandan judges would immediately understand the full meaning and all the nuances of the testimonies given in their common mother tongue. However, just as it was never envisaged to establish the ICTR on Rwandan soil, no mention has been found that the UN ever considered appointing Rwandan judges throughout the Tribunal's existence. The issue of the sociocultural distance separating the judicial structure and the legal practitioners of the ICTR from the Rwandans appearing in its courtrooms therefore remains a constant factor to be taken into account when looking at the trials themselves.

The question of which languages would be used at the ICTR was concisely addressed in the second-last article of the Tribunal's Statute: 'The working languages of the International Tribunal shall be English and French.' [44, p. 15] In other words, the UN was catering solely for the parameters of the ICTR's judicial and other administrative staff, in accordance with the language policy conventionally observed by international bodies. Remarkably, at this stage, little if any attention appears to have been given to the question of which language(s) would be used by the Rwandan nationals who would in fact be crucial participants in the day-to-day courtroom activities. In fact, the vast majority of Rwandan witnesses appearing before the Tribunal preferred to give their testimonies in Kinyarwanda. This failure to recognise the prime importance of making adequate provision for the language needs of the Tribunal has been noted not only in the case of the ICTR, but also at the International Criminal Tribunal for the former Yugoslavia (ICTY), both of which 'had difficulty keeping up with their need for language translation, even though the languages in need of translating have been known from the tribunals' inceptions.' [6, p. 33] Although a shortage of suitably qualified Rwandan translators and interpreters was indeed a practical reality in the wake of the 1994 genocide, the preceding comment suggests an ongoing disregard on the part of the UN for the integral role of language within the judicial process as a crucial tool for the effective communication of evidence. The care taken by legal professionals to use precise terminology and the cross-examination of 
witnesses to identify nuances of meaning in their testimonies have become automatic procedural reflexes in national courtrooms worldwide, within each of which all participants are deemed to speak and understand the same language. The enormous difficulty of ensuring the same rigour in an international tribunal across multiple languages was a challenge that many of the participants explicitly acknowledged at various points. One of Akayesu's defence lawyers, Michael Karnavas, made the following observation in October 1996, even before the trial began:

If I present a statement in English to someone who speaks Kinyarwanda and I say please tell me if this is accurate and correct, please tell me if the translations were accurate and correct, how can, how can you, the bench, assess whether that statement was accurate and correct? [23, p. 47.]

The approach adopted by Karnavas and by Akayesu's subsequent defence counsel in questioning the witnesses throughout the trial, primarily focused on identifying inconsistences between the previous statements the witnesses had given to investigators in Rwanda, and the evidence they were now giving in the ICTR courtroom. [See for example 20] This strategy of seeking to undermine the credibility of a hostile witness is standard defence practice in Western common law courtrooms and it can be an effective technique in that environment because all the persons involved in the proceedings can be assumed to frame their perception of events in relation to the same set of temporal and spatial markers regarding factual details such as time of day, dates, distance, and so on. However, these same markers were not an integral part of the world view of the largely agricultural and illiterate population comprising Rwandan society in 1994, as Rwandan linguist Mathias Ruzindana has explained in an article about the 'cultural collision' that occurred at the ICTR. [38, pp. 147-150] Both the prosecution and the defence constantly sought precision from the witnesses regarding the exact date, the exact time of day, the length of time, the number of times, the exact location, the distance between locations and so on. Similarly, in relation to issues of terminology, the defence lawyers were particularly keen to establish an exact English and French meaning for Kinyarwanda words. As Ruzindana notes: 'the defense tends to interpret polysemic key terms in a narrow sense, rejecting figurative and extended usages.' [38, p. 147] In this regard, their approach was very different from that of the prosecution, who recognised the importance of elucidating all the potential nuances of these terms in order to determine their value within the context of the genocide.

\section{The Akayesu trial and the specific challenges surrounding the evocation of the crime of rape}

Jean-Paul Akayesu was initially indicted on twelve counts of genocide, crimes against humanity and violations of Common Article 3 of the Geneva Convention. The transcript of the opening day of Akayesu's trial contains extensive background information on Akayesu's position in the local community. He was a popular and respected former school teacher who had been elected 'bourgmestre' (mayor) in the municipality of Taba in central Rwanda in April 1993, a position he occupied until he fled from Rwanda in June 1994. A detailed explanation of the sociocultural significance of the role of bourgmestre is provided by the Prosecutor:

It is an extremely important position in Rwanda, your Honors, one which carries powers beyond those prescribed by law. Bourgmestres are held in a high position of high esteem in their commune. Citizens come to them for advice and to informally settle disputes. You will hear that it is the most important and prestigious local position one can hold in Rwanda, on a local level. The word of the bourgmestre, in fact, is the law. [25, p. 34.] 
In the early days of the genocide that began on 6 April 1994, Akayesu had initially sought to fulfil his mandate to protect the residents in his municipality. However, at a meeting he attended on 18 April with ministers of Rwanda's provisional government, their instructions were categorical: 'Soit vous vous rangez de notre côté et vous appuyez les tueries ou vous perdez votre position d'autorité.' (Either you side with us and support the killings or you lose your position of authority.) [24, p. 41] Following that meeting, Akayesu's behaviour indicated his compliance with those instructions, although he himself did not directly carry out any killings. At the ICTR, the prosecution argued that Akayesu had been responsible for direct and public incitement to commit genocide, and that his audience in the municipality of Taba had been in no doubt as to the meaning of his words. This fact was attested very simply and clearly by the first witness to take the stand, known only as 'Witness $\mathrm{K}$ ' by virtue of the ICTR's witness protection plan. In response to the Prosecutor's question whether Akayesu had killed 'with his own hands', the witness' response was: 'Non, il a tué par ordre. (No, he killed by order.)' [26, p. 92]

Rape did not figure among the original charges brought against Akayesu. Prior to the commencement of the courtroom proceedings in Arusha, investigators had been sent to Rwanda to collect preliminary evidence in the form of witness statements. [See for example 28, pp. 31-32] During this initial phase, it was deemed that insufficient evidence had been collected to merit the inclusion of rape in the indictments brought against Akayesu. Jonneke Koomen cites several studies, including a Human Rights Watch report from 1996, attesting that 'few of these international investigators asked Rwandan women about sexual violence.' $[14$, p. 258] Koomen also notes the experiences of women interviewed by American journalist Elizabeth Neuffer in Akayesu's own district of Taba, who said 'they found it difficult to approach investigators, 'mostly white males', who "'roared into the villages in their white UN Jeeps and then treated survivors with condescension." [14, p. 258] Such negative perceptions undoubtedly impacted on the witnesses' willingness to provide details of such personal and traumatic experiences as rape in their pre-trial statements. However, there was an unexpected mention of rape in the ICTR courtroom in the course of the prosecutor's questioning of Witness J on 27 January 1997:

Witness: Par après je me suis rendue à Kabgayi. (Afterwards I went to Kabgayi.)

Prosecutor: Did anybody go with you? ${ }^{2}$

Witness: J'étais avec ma fille qu'on avait violée. (I was with my daughter who had been raped.)

Prosecutor: When was she raped?

Witness: Ils l'ont violée quand ils ont tué mon père. (They raped her when they killed my father.)

Prosecutor: How many men did rape your daughter?

Witness: Trois hommes. (Three men.)

Prosecutor: Was this question ever put to you by the investigators of the Tribunal?

Witness: Non, ils ne m'ont pas posé cette question. (No, they didn't ask me this question.)

Prosecutor: Did Akayesu ever come to Kabgayi?

Witness: Oui j'ai vu Akayesu à Kabgayi. (Yes I saw Akayesu in Kabgayi.)

Prosecutor: I would like to ask you one question which I skipped concerning the rape of your daughter. How old was your daughter?

Witness: Elle était âgée de six ans. (She was six years old.) [20]

\footnotetext{
${ }^{2}$ As noted above, the American Prosecutor Pierre-Richard Prosper spoke in English. His words are therefore cited directly in that language.
} 
Beth Van Schaak has commented that this key testimony 'emerged somewhat randomly. If J had not offered the fact that her six-year-old daughter had been raped, the existence of sexual violence in Taba Commune may never have made it into the formal record.' [45, p. 7] Both the president of the Tribunal, Justice Laïty Kama and Justice Lennart Aspegren asked follow-up questions regarding the rape, particularly with regard to the potential involvement of Jean-Paul Akayesu. Van Schaak finds it "noteworthy how few details were solicited from the witnesses, almost as if no one wanted to touch the material or failed to immediately recognize its significance.' [45, p. 7] However, the main focus of attention at this point was the pursuit of evidence of direct incitement on the part of Akayesu, which remained the guiding preoccupation of the courtroom discussion. A more detailed account of the sexual violence perpetrated with Akayesu's knowledge and encouragement emerged in the testimonies of Witness H on 6 and 7 March 1997, again as part of the overall narrative of events occurring on that day. She describes the scene at the 'bureau communal' (municipal office), where she observed women been raped in the presence of Akayesu who 'ne disait rien de ce qui se faisait' (didn't saying anything about what was being done). [21]

The revelations regarding rape contained in the testimonies of Witness $\mathbf{J}$ and Witness $\mathrm{H}$ inspired the prosecution to undertake further investigations. Through a fortuitous synchronicity in internal and external dynamics at the ICTR during this period, an Amicus curiae was also lodged on 27 May 1997 by various women's groups who were concerned about the Tribunal's failure to undertake prosecution of sexual violence. [See 37, p. 59] The prosecution's request to add three further charges relating to rape and sexual violence to the existing charges against Akayesu was approved and an amended indictment was issued on 17 June 1997. The Tribunal's motivation in authorising the new indictment is explained in the September 1998 judgment:

(...) Chamber takes note of the interest shown in this issue by non-governmental organizations, which it considers as indicative of public concern over the historical exclusion of rape and other forms of sexual violence from the investigation and prosecution of war crimes. The investigation and presentation of evidence relating to sexual violence is in the interest of justice. [34, para 417]

Legal scholars have commented that it is extremely unusual and irregular for new charges to be laid at such an advanced stage in the proceedings. Nancy Combs, for example, observes that rape charges brought so late in the day would not be permitted in a Western court, as the witness' statement would not be deemed credible because of its tardy submission. [7, p. 87 . Also see 4, p. 224] In this regard, it must be said that as the first case to be heard at the Tribunal, the Akayesu trial attests to a remarkable willingness on the part of the judiciary to respond to the very particular sociocultural characteristics it was encountering, particularly in terms of the language used to present evidence regarding the crime of rape.

Mention has been made above of the reticence of Rwandans to speak of topics of a sexual nature. However, further insight into how rape is perceived within Rwandan society is required to fully appreciate the ramifications of the testimonies regarding rape presented during the Akayesu trial. In this connection, valuable information is contained in the report by the communications officer for the Pro Femmes association, Marie Immaculée Ingabire entitled Viols des Femmes Tutsis comme Armes du Génocide de 1994 (Rapes of Tutsi Women as Weapons of the 1994 Genocide). [12] This report was submitted to the ICTR in 2004 in the Muhimana case: 
Etre victime de viol pour une fille ou une femme Rwandaise constitue un problème socioculturel pour elle. En temps normal, la société rwandaise n'a pas l'habitude de regarder une femme violée comme une victime, qui a besoin de compassion, de réhabilitation, on la regarde plutôt comme si elle avait une part de responsabilité dans l'affaire. Cela fait partie de la mentalité des Rwandais, et les femmes violées pendant le Génocide ne l'ignorent pas. Elles savent donc que elles [sic] feront toujours l'objet d'une certaine stigmatisation si voilée soit-elle. Elles savent que c'est comme si on les avaient marqué [sic] au fer rouge. (To be the victim of rape for a Rwandan girl or woman constitutes a sociocultural problem for her. In normal times, Rwandan society is not accustomed to seeing a raped woman as a victim who needs compassion and rehabilitation. She is rather looked upon as if she had a share of responsibility in the matter. That is part of the mentality of Rwandans and women who were raped during the genocide are not ignorant of that fact. They therefore know that they will always be the object of a certain stigmatisation, however veiled it may be. They know that it is as if they had been branded with a hot iron.) [12, p. 4]

In light of this information, the Akayesu trial can also be seen as groundbreaking with regard to the courage of the female witnesses to evoke the crime of rape in the extremely alien context of an international courtroom. As a result of the amended indictment lodged against Akayesu, an adjournment was called to allow for adequate preparation by both the prosecution and the defence to address the new charges. After the trial reopened on 23 October 1997, five female witnesses, identified only by the initials JJ, OO, KK, NN and PP, testified to Akayesu's personal direct involvement in inciting rape at the municipal office.[See 27, 28, 29, 22, 30, 31, $32,33]$

It is important to note at this point that there is no actual word in Kinyarwanda for the act of rape. At the Akayesu trial, four terms are mentioned as being used 'interchangeably' by witnesses; the literal translation of these terms is provided here in brackets: 'gusambanya' (to commit adultery); 'kurongora' (to have sexual intercourse with a woman/to marry); 'kuryamana' (to share a bed with/to have sexual intercourse) and 'gufata ku ngufu' (to take by force). The first three expressions reflect the sociocultural context in Rwanda within which the sexual act occurs and where the status of marriage is an explicit or implicit point of reference. Koomen, for example, notes that 'to the frustration of ICTR prosecution lawyers, Rwandan witnesses often use the phrase "we got married" to describe how they were raped.' [14, p. 265] In fact the core consideration in rape of whether the sexual act was consensual or not is completely absent from the semantic associations of these terms in Kinyarwanda. This constitutes one of the intrinsic difficulties in establishing a linguistic equivalence between these words and the terms 'rape' in English or 'viol' in French, both of which carry connotations of 'forced violation' and 'unlawful non-consensual penetration.' The fourth Kinyarwanda expression 'gufata ku ngufu' does explicitly contain the notion of force; this factor was noted as being of significance in satisfying the Tribunal that it could appropriately be translated as rape. [34, para 154.]

An example of the difficulties encountered by interpreters in finding appropriate translations for the original Kinyarwanda terms can be found in the testimony of Witness OO:

INTERPRETER: Ils sont retournés près du bureau communal. Ils ont dit à Akayesu "Ces filles, nous les amenons et on va... les... les..." (pause) (checks with witness) Kubarongora? (witness confirms) "Nous allons coucher avec eux." (They went back near the municipal office. They said to Akayesu "These girls, we are taking them and 
we are going to ..... them .....them" (pause) (checks with witness) Kubarongora? (witness confirms) "We are going to have sex with them.")

PROSECUTOR: Were those the exact words ?

INTERPRETER: Qu'ils allaient nous... qu'ils allaient dormir avec nous, quoi. Coucher avec nous. Qu'ils allaient nous amener pour coucher avec nous. (That they were going to .... us.... that they were going to sleep with us. Have sex with us. That they were going to take us to have sex with us.) [22]

The interpreter's hesitation in finding the most appropriate verb initially lead her to formulate an incomplete syntactical structure that highlights the girls' position as the object of the action through the repetition of the pronoun object 'les': 'We are taking them and we are going to (?) them... (?) them...' The French term 'coucher' conveys the notions of sleeping with someone or having sex with someone, whereas 'dormir' contains no sexual connotations and evokes the act of sleeping. The English version of this same section uses the verbs 'to sleep with' and 'to make love to.' [30, p. 21.] What is missing from both the French and the English versions are all the important cultural connotations of the original Kinyarwanda verb, 'kurongora.' Françoise Ngendahayo, advisor on gender issues and assistance to victims at the ICTR, has made the following observations in this regard with reference to the Akayesu trial:

Dans la culture rwandaise et burundaise, le mot "viol" est confondu avec le mot "mariage". (...) Par exemple, le mot "kurongora" (...) insinue une banalisation du crime de violence sexuelle. Ceci insinue que ce crime était considéré comme normal, comme une "forme de mariage." Donc, cela montre dans quelle mesure la philosophie du viol est presque tolérée dans notre culture et que, peut-être, les gens qui l'ont perpétré croyaient que c'était une continuation d'exploitation, comme on le dit, du "butin de guerre." (In the Rwandan and Burundian culture, the word "rape" is confused with the word "marriage." For example, the word "kurongora" (...) insinuates a normalisation of the crime of sexual violence. This insinuates that this crime was considered as normal, like a "form of marriage." Therefore this shows to what extent the philosophy of rape is almost tolerated in our culture and that, perhaps, the people who perpetrated it believed that it was a continuation of the exploitation of the so-called "spoils of war.") [5]

The fact that the act of rape was not represented by its own specific designated term in Kinyarwanda and that it was not considered a criminal act in Rwandan society created an enormous conceptual gulf that the ICTR translators and interpreters can be clearly observed to struggle with during the proceedings in this first trial.

A number of testimonies in Kinyarwanda in written, video and audio format now exist outside the ICTR framework in relation to the crime of rape committed during the genocide. Although a detailed analysis of those testimonies falls outside the parameters of this article, it is nevertheless pertinent to note that euphemisation is an ubiquitous linguistic device used by rape victims and witnesses to convey the fact that this highly traumatic event had occurred. The formulations that are used are often very elliptical, where the surface meaning of the actual words is too neutral or too vague to be construed as categorically referencing an act of violence. An example of the challenge of interpreting such euphemistic terms can be found in the Akayesu trial in the testimony of Witness JJ given on 23 October 1997. A common expression used by Rwandan women to describe rape is 'He did what he wanted/They did what they wanted.' [See for example 39] Witness JJ's actual words in Kinyarwanda do not appear in the transcriptions; however, from the discussion that followed, it can be assumed that this was the 
formulation she used. In this part of her testimony she is talking about the actions of the 'Interahamwe', the militia responsible for carrying out many of the killings during the genocide:

WITNESS : Ils prenaient des jeunes filles et des femmes dans une forêt qui était aux environs. Ils ont commencé à les violer. (They took young girls and women to a forest nearby. They started to rape them.)

PROSECUTOR : Did you witness these rapes?

WITNESS : Je le voyais. (I saw it.)

PRESIDENT : (to Akayesu, who had raised his hand) Je vous donne la parole. (You may speak.)

AKAYESU: Je vous remercie Monsieur le President. On a posé une question au témoin qui a répondu qu'on prenait les jeunes filles dans les forêts et on en faisait ce qu'ils voulaient. Ensuite, on a introduit la notion de viol. Je crois que parler de "viol", ne seraitce que le mot "viol"... (Thank you Mr. President. A question was put to the witness who replied that they took young girls to the forests and did what they wanted with them. Then the notion of rape was introduced. I think that talking about "rape", even the word itself "rape"...)

PRESIDENT : Qui a introduit la notion de viol ?... C'est l'interprète ? (Who introduced the notion of rape?... The interpreter?)

AKAYESU : Oui. J'ai entendu la notion de viol ensuite alors que le témoin a dit qu'on en faisait ce qu'ils voulaient. Je crois qu'il y a quand même une nuance. (Yes. I heard the notion of rape after, whereas the witness said that they did what they wanted with them. I think there is nevertheless a nuance.) [27, pp. 64-65.]

Before discussing the content of this exchange, the fact that the accused is permitted by the President to intervene should first be elucidated. Jean-Paul Akayesu was a fluent French speaker, as befitting his role as a local government figure required to conduct business in both Kinyarwanda and the country's second official language, French. Within the ICTR courtroom, his mastery of French meant he was able to express himself in a language that would be directly understood by the then President of the Tribunal, Justice Laity Kama, a Senegalese national, as well as other members of the international judiciary. The Prosecutor also stated from the first day of proceedings that Akayesu's fluency in both French and Kinyarwanda meant that he himself could raise any concerns about the accuracy of the interpretation into French. [24, p. 60.] In this instance, Akayesu's remarks reflect one of the frequent strategies adopted by those seeking to deflect attention from the actual intended meaning of euphemistic formulations. He insists that the interpretation of those words should be restricted to the purely denotational values of the terms in question. Here, 'they did want they wanted' is so vague that it cannot be deemed to be irrefutably synonymous with an act of aggression. Akayesu then encourages the view that it was the interpreter who introduced the term 'rape' whereas this term was not present in the original testimony in Kinyarwanda by the witness. Calling into question the professional competence and impartiality of the interpreters, most of whom were of Tutsi ethnicity, was also a common occurrence at the ICTR, particularly on the part of defence lawyers seeking to attenuate the guilt of their clients. However, as the discussion in the preceding pages has demonstrated, the use of the term 'rape' by the interpreter cannot be considered an unethical distortion of the original formulation. Instead, it reflects the interpreter's professional responsibility to translate the intended meaning of the discourse that is embedded under the strictly denotational level by virtue of the sociocultural conventions of its context of expression. 
The extracts cited above all contain expressions that can be regarded as euphemistic replacements for more explicit language. However, it is also important to note the common use of even more elliptical rhetorical strategies. For example, Witness JJ conveys the information that she was raped more than once by stating: 'Il a terminé la première fois et il a terminé une deuxième fois.' (He finished the first time and he finished a second time.) [27, p. 69] In order to decode the meaning of such utterances, the audience must themselves complete the missing elements based on their own knowledge of the context of the events being described. A similar observation can be made in relation to evidence establishing Akayesu's guilt with regard to the charge of incitement to genocide as well as rape. The Judgment of 2 December 1998 cites a phrase attributed to Akayesu as he addressed the Interahamwe: 'nababwiye ko muzajya mubanza mukirwanaho mukarongora abo bakobwa.' (I told you that should start by doing something for yourselves and have sex with those girls.) [34, para 429] The act of rape is expressed here through the verb 'kurongora' that was discussed in detail above. What is otherwise noteworthy in this statement is the verb 'kubanza', meaning to start by doing something. The use of this verb sets up the expectation that the initial act of rape will be followed by a further act: by implication, in this context of genocide, that would have been understood as referring to the act of killing. However, there is no verbalised direct instruction or incitement to kill in this sentence. Taking such indirect modes of expression into consideration was therefore crucial in evaluating Akayesu's criminal responsibility. [Also see 13, p. 27] In this connection, it is significant that the Tribunal determined that 'the direct element of incitement should be viewed in the light of its cultural and linguistic content', and that 'incitement may be direct, and nonetheless implicit.' [34, para 557]. More specifically:

(...) in light of the culture of Rwanda and the specific circumstances of the instant case, acts of incitement can be viewed as direct or not, by focusing mainly on the issue of whether the persons for whom the message was intended immediately grasped the implication thereof. [34, para 558].

In this regard, the Akayesu case established a valuable precedent for subsequent trials at the ICTR, notably in the so-called Media Case, where it provided 'the only direct precedent' for the interpretation of direct and public incitement to genocide and where the 'context of Rwandan culture and language' was again identified as being a prime consideration. [35, para 1011.]

\section{Conclusion}

At a conference held in Geneva in 2009 to invite the 'stakeholders' in the ICTR to reflect on its contributions, the former ICTR President Dennis Byron remarked that:

The accomplishment of the Tribunal in confronting this brutal reality [of the genocide] cannot be overestimated. (...) Again I quote the UN Division for the Advancement of Women commenting on the historic conviction of the former mayor of the Rwandan town of Taba, Jean Paul Akayesu, "In making rape part of the perpetrator's conviction of genocide, the Tribunal had advanced the world treatment of rape and sexual violence and begun the long process of reversing the climate of impunity that sexual crimes in wars had enjoyed." [5]

As mentioned at the beginning of this article, during the Akayesu case, the perception among the judicial body at the ICTR was that their own best practice would create the blueprint 
and the procedural ground rules for the cases to follow. It could be argued that they were perhaps approaching the pursuit of justice more idealistically than was the case in subsequent years, when other pressures, such as growing international dissatisfaction with the amount of time taken to resolve cases, impacted on the prosecution's willingness to add rape to the list of indictments.[See 19, p. 8] Certainly the Akayesu case is significant in its almost 'organic' approach to justice, as demonstrated by its willingness to construct and integrate three completely new indictments for rape based on the strength of the evidence tendered by the witnesses within the framework of the courtroom. The subsequent handling of the evidence provided by the additional witnesses called to elucidate Akayesu's actual role in relation to the crime of rape also demonstrates an appreciable degree of open-mindedness on the part of the judiciary regarding the impact of sociocultural factors on the way crucial evidence was expressed, often euphemistically or elliptically. The extreme violence characterising the genocide in Rwanda is often evoked using the hyperbolic epithet of 'unspeakable', but in the Akayesu case, the work of the interpreters and translators was exemplary in effectively articulating the crimes of rape and incitement to genocide.

The preceding discussion has provided some insight into the complexity of the challenges faced by interpreters and translators as co-creators and mediators of meaning, particularly of key terms, within the judicial context. By extension, it argues for more systematic recognition and resourcing of these language professionals in all international judicial structures, given that they play such a vital role in the dispensation of appropriate judgement and sentencing. Thus, the 'best practice' that was consciously adopted in the Akayesu trial with regard to its acknowledgement of the importance of accurately 'decoding' the witnesses testimonies can indeed be seen as a valuable 'roadmap', not only for the ICTR but for all international criminal courts, in the pursuit of the essential objective of ensuring a fair trial.

\section{References}

1. Alvarez, Jose. 1999. Crimes of States/Crimes of Hate: Lessons from Rwanda. Yale Journal of International Law 24 - 2: 265-483.

2. Angelelli, Claudia and Baer, Brian eds. 2016. Researching Translation and Interpreting. London and New York: Routledge.

3. Askin, Kelly. 2003. Prosecuting Wartime Rape and Other Gender-Related Crimes under International Law: Extraordinary Advances, Enduring Obstacles. Berkeley Journal of International Law, 21 - 2: 288-349.

4. Chenault, Suzanne. 2008. And since Akayesu - The Development of ICTR Jurisprudence on Gender Crimes: A Comparison of Akayesu and Muhimana. New England Journal of International and Comparative Law 14: 221-237.

5. Colloque international : Modèle ou contre-modèle pour la justice pénale internationale ? Le point de vue des acteurs. 2009. https://genevaconference-tpir.univ-paris1.fr/laconference,401.html. Accessed 14 September 2020. 
6. Combs, Nancy. 2007. Guilty Pleas in International Criminal Law, Palo Alto: Stanford University Press.

7. Combs, Nancy. 2010. Fact-Finding without Facts: The Uncertain Evidentiary Foundations of International Criminal Convictions, Cambridge: University Press.

8. De Beer, Anna-Marie. 2020. Sharing the Burden of Stories from the Tutsi Genocide; Rwanda: écrire par devoir de mémoire. Cham: Palgrave Macmillan.

9. De Brouwer, Anne-Marie. 2005. Supranational Criminal Prosecution of Sexual Violence: The ICC and the practice of the ICTY and the ICTR, Antwerp and Oxford: Intersentia.

10. Elias-Bursać, Ellen. 2012. Shaping International Justice. The Role of Translation and Interpreting at the ICTY in The Hague. Translation and Interpreting Studies, 7 - 1: 34-53.

11. Halliday, Michael. 2014. Halliday's Introduction to Functional Grammar, rev. C. Matthiessen, $4^{\text {th }}$ edn., London and New York: Routledge.

12. Ingabire, Marie. 2004. Viols des Femmes Tutsis comme Armes du Génocide de 1994. Submitted in Prosecutor v. Muhimana, International Criminal Tribunal for Rwanda, Case No. ICTR-95-1-B Record No. ICTR-95-1B-0174/1.

13. Karton, Joshua. 2008. Lost in Translation: International Criminal Tribunals and the Legal Implications of Interpreted Testimony. Vanderbilt Journal of Transnational Law, 41 - 1: $1-54$.

14. Koomen, Jonneke. 2013. 'Without These Women, the Tribunal Cannot Do Anything': The Politics of Witness Testimony on Sexual Violence at the International Criminal Tribunal for Rwanda. Signs: Journal of Women in Culture and Society, 38 - 2: 253-277.

15. Martin, Jim and Rose, David. 2008. Genre Relations: Mapping Cultures, London: Equinox Publishing Ltd.

16. Matthiessen, Christian. 2019 Register in Systemic Functional Linguistics. Register Studies. https://doi.org/10.1075/rs.18010.mat.

17. McKinley Jr. James. 1998. U.N. Tribunal, in First Such Trial Verdict, Convicts Rwandan Ex-Mayor of Genocide. New York Times, 3 September 1998. https://www.nytimes.com/1998/09/03/world/un-tribunal-in-first-such-trial-verdictconvicts-rwandan-ex-mayor-of-genocide.html. Accessed 28 August 2020.

18. Moghalu, Kingsley. 2005. Rwanda's Genocide: The Politics of Global Justice. New York and Basingstoke: Palgrave Macmillan.

19. Nowrojee, Binaifer. 2005. 'Your justice is too slow'. Will the ICTR Fail Rwanda's Rape Victims?. United Nations Research Institute for Social Development (UNRISD) Occasional Paper 10. www.unrisd.org/publications/opgp10. Accessed 27 August 2020.

20. Prosecutor v. Akayesu (Audio Recording - Floor) International Criminal Tribunal for Rwanda, Case No. ICTR-96-4-T, 27 January 1997). 
21. Prosecutor v. Akayesu (Audio Recording - Floor) International Criminal Tribunal for Rwanda, Case No. ICTR-96-4-T, 6 March 1997.

22. Prosecutor v. Akayesu (Audio Recording - Floor) International Criminal Tribunal for Rwanda, Case No. ICTR-96-4-T, 27 October 1997.

23. Prosecutor v. Akayesu (Redacted Transcript - English) International Criminal Tribunal for Rwanda, Case No. ICTR-96-4-T, 31 October 1996.

24. Prosecutor v. Akayesu (Redacted Transcript - French) International Criminal Tribunal for Rwanda, Case No. ICTR-96-4-T, 9 January 1997.

25. Prosecutor v. Akayesu (Redacted Transcript - English) International Criminal Tribunal for Rwanda, Case No. ICTR-96-4-T, 9 January 1997.

26. Prosecutor v. Akayesu (Redacted Transcript - French) International Criminal Tribunal for Rwanda, Case No. ICTR-96-4-T, 10 January 1997.

27. Prosecutor v. Akayesu (Redacted Transcript - French) International Criminal Tribunal for Rwanda, Case No. ICTR-96-4-T, 23 October 1997.

28. Prosecutor v. Akayesu (Redacted Transcript - French) International Criminal Tribunal for Rwanda, Case No. ICTR-96-4-T, 24 October 1997.

29. Prosecutor v. Akayesu (Redacted Transcript - French) International Criminal Tribunal for Rwanda, Case No. ICTR-96-4-T, 27 October 1997.

30. Prosecutor v. Akayesu (Redacted Transcript - English) International Criminal Tribunal for Rwanda, Case No. ICTR-96-4-T, 27 October 1997.

31. Prosecutor v. Akayesu (Redacted Transcript - French) International Criminal Tribunal for Rwanda, Case No. ICTR-96-4-T, 31 October 1997.

32. Prosecutor v. Akayesu (Redacted Transcript - French) International Criminal Tribunal for Rwanda, Case No. ICTR-96-4-T, 03 November 1997.

33. Prosecutor v. Akayesu (Redacted Transcript - French) International Criminal Tribunal for Rwanda, Case No. ICTR-96-4-T, 04 November 1997.

34. Prosecutor v. Akayesu (Trial Judgment) International Criminal Tribunal for Rwanda, Case No. ICTR-96-4-T, 2 September 1998.

35. Prosecutor v. Nahimana, Barayagwiza and Ngeze (Trial Judgment) International Criminal Tribunal for Rwanda, Case No. ICTR-99-52-T, 3 December 2003.

36. Pym, Anthony, Schlesinger, Miriam and Jettmarová, Zuzana. 2006. Sociocultural Aspects of Translating and Interpreting. Amsterdam and Philadelphia: John Benjamins Publishing Company. 
37. Rovetta, Ornella. 2014. Le Procès de Jean-Paul Akayesu: les autorités communales en jugement. Vingtième Siècle Revue d'histoire, 122 - 2 : 51-61.

38. Ruzindana, Mathias. 2012. The Challenges of understanding Kinyarwanda key terms used to instigate the 1994 genocide in Rwanda. In Propaganda, War Crimes Trials and International Law, ed. Predrag Dojčinović, 145-170. Milton Park: Routledge.

39. Rwanda 1994 genocide.

http://www.youtube.com/watch?v=psDMVn2ZBJM\&feature=related. Accessed 14 September 2020.

40. Rwigamba, Balinda, Nkusi, Laurent and Ruzindana, Mathias. 1998. The Kinyarwanda Language: Its Use and Impact in the Various Media during the Period 1990-1994. A Sociolinguistic Study. Submitted in Prosecutor v. Nahimana et al, International Criminal Tribunal for Rwanda, Case No. ICTR-99-55-T (Exhibit P110A).

41. Schabas, William. 1997. Justice, Democracy and Impunity in Post-Genocide Rwanda: Searching for Solutions to Impossible Problems. Criminal Law Forum, 7 - 3: 523-560.

42. Stern, Ludmila. 2011. Courtroom interpreting. In Oxford Handbook of Translation Studies, ed. Kirsten Malmkjaer and Kevin Windle. https://www.oxfordhandbooks.com/. Accessed 20 August 2020.

43. Swigart, Leigh. 2015. African Languages in International Criminal Justice: The International Criminal Tribunal for Rwanda and Beyond. In Promoting Accountability under International Law for Gross Human Rights Violations in Africa: Essays in Honour of Prosecutor Hassan Bubacar Jallow ed. Charles Jalloh and Alhagi Marong, 578-611. Leiden: Brill.

44. UN Resolution 955. 1994. Establishment of an International Tribunal and Adoption of the Statute of the Tribunal. S/RES/995 8 November 1994.

45. Van Schaak, Beth. 2008. Engendering Genocide: The Akayesu Case before the International Criminal Tribunal for Rwanda. Santa Clara University School of Law, Legal Studies Research Papers Series, Working Paper No. 08-55. 